\title{
Pengembangan Media Pembelajaran Daring Komik Virtual dalam Muatan Materi Gagasan Pokok dan Gagasan Pendukung Bahasa Indonesia
}

\section{Ni Kadek Dwi Darmayanti*, Ida Bagus Gede Surya Abadi²}

1,2 Jurusan Pendidikan Dasar, Universitas Pendidikan Ganesha, Singaraja, Indonesia

\author{
A R T I C LE I N F O \\ Article history: \\ Received 10 Januari 2021 \\ Received in revised form \\ 30 Januari 2021 \\ Accepted 11 Maret 2021 \\ Available online 25 April \\ 2021 \\ Kata Kunci: \\ Pengembangan, Komik \\ Virtual, Bahasa \\ Indonesia \\ Keywords: \\ Development, Virtual \\ Comics, Indonesian \\ Language
}

\begin{abstract}
A B S T R A K
Kurangnya literasi siswa dan terbatasnya media pembelajaran yang digunakan dalam pembelajaran Bahasa Indonesia menjadi alasan utama penelitian ini dilakukan. Tujuan penelitian ini adalah untuk menganalisis pengembangan media pembelajaran daring Komik Virtual dalam muatan materi gagasan pokok dan gagasan pendukung Bahasa Indonesia. Penelitian ini merupakan penelitian pengembangan dengan menggunakan model $A D D I E$. Subjek penelitian ini adalah validitas media pembelajaran daring Komik Virtual dalam muatan materi gagasan pokok dan gagasan pendukung Bahasa Indonesia. Metode pengumpulan data yang digunakan dalam penelitian ini menggunakan metode non-tes dengan penyebaran instrumen kepada para ahli. Instrumen yang digunakan berupa kuisioner/angket. Analisis data yang digunakan adalah teknik analisis deskriptif kuantitatif. Hasil penelitian ini menunjukkan bahwa media pembelajaran daring komik virtual berdasarkan hasil review ahli isi mata pelajaran memperoleh persentase $90,00 \%$, ahli desain pembelajaran memperoleh persentase 92,00\%, ahli media pembelajaran memperoleh pesentase 95,00\%, dan hasil uji coba
\end{abstract} peorangan memperoleh persentase 92,35\%. Simpulan penelitian ini adalah media pembelajaran daring Komik Virtual secara keseluruhan termasuk kedalam kategori sangat baik dan layak untuk digunakan dalam pembelajaran muatan Bahasa Indonesia materi gagasan pokok dan gagasan pendukung. Implikasi dari pelaksanaan penelitian ini adalah dapat digunakan oleh guru sebagai sumber belajar sehingga dapat meningkatkan minat siswa untuk belajar.

\begin{abstract}
A B S T R A C T
Lack of student literacy and the limited learning media used in Indonesian language learning are the main reasons for this study. The purpose of this research is to analyze the development of online learning media for Virtual Comics in the content of the main ideas and supporting ideas of Indonesian Language. This research is a development research using the ADDIE model. The subject of this research is the validity of online learning media for Virtual Comics in the content of the main ideas and supporting ideas of Indonesian Language. The data collection method used in this study used the non-test method with the distribution of instruments to experts. The instrument used was a questionnaire / questionnaire. The data analysis used was quantitative descriptive analysis technique. The results of this study indicate that the virtual comic online learning media based on the results of the subject content expert's review obtained a percentage of $90.00 \%$, learning design experts obtained a percentage of $92.00 \%$, learning media experts obtained a percentage of $95.00 \%$, and the results of individual trials obtained percentage $92.35 \%$. The conclusion of this research is that the virtual comic online learning media as a whole is included in the very good category and is suitable for use in learning Indonesian content on the main ideas and supporting ideas. The implication of the implementation of this research is that it can be used by teachers as a learning resource so that it can increase student interest in learning.
\end{abstract}




\section{Pendahuluan}

Merebaknya wabah pandemi Covid-19 di seluruh dunia, khususnya Indonesia memberikan dampak yang begitu terasa khususnya dalam bidang pendidikan. Dampak dari adanya wabah pandemi Covid-19 dalam bidang pendidikan yakni terjadinya transformasi pelaksanaan proses pembelajaran yang awalnya dilakukan secara tatap muka di kelas menjadi dilaksanakan secara virtual atau dikenal dengan pembelajaran daring. Pembelajaran daring merupakan pemanfaatan jaringan internet dalam pelaksanaan pembelajaran dengan menggunakan beberapa aplikasi seperti classroom, video converence, telepon atau live chat, zoom maupun melalui whatsapp group. Pembelajaran daring dapat dilakukan dengan menggabungkan beberapa jenis sumber belajar seperti dokumen, gambar, video, audio dalam pembelajaran (Anugrahana, 2020; Putria et al., 2020; Yunitasari \& Hanifah, 2020). Pada pelaksanan pembelajaran daring untuk meghasikan pembelajaran yang efektif tentunya harus didukung dengan penggunaan media pembelajaran.

Media pembelajaran dapat diartikan sebagai suatu alat atau perantara yang dapat digunakan untuk memudahkan pelaksanaan kegiatan pembelajaran sehingga dapat mengefektifkan komunikasi antara guru dan siswa (Maharwati, 2019; Maufur \& Lisnawati, 2017; Ulfah \& Soenarto, 2017). Apalagi melihat perkembangan kognitif pada usia SD masuk pada tahap operasional kongkret, dimana anak sudah mampu berpikir logis, memahami konsep percakapan, mengorganisasikan objek ke dalam klasifikasi dan mampu mengingat, memahami serta memecahkan masalah yang bersifat konkret. Sehingga penggunaan media pembelajaran sangat penting dalam pelaksanaan pembelajaran, salah satunya dalam pembelajaran Bahasa Indonesia.

Pembelajaran bahasa Indonesia berdasarkan kurikulum 2013 menganut pendekatan komunikatif (integratif tematik) yang dalam implementasinya pembelajaran bahasa Indonesia lebih menekankan pada aspek komunikasi dan aplikasi. Bahasa Indonesia merupakan mata pelajaran yang dapat dipelajari secara langsung dalam kehidupan sehari-hari (Budi Febriyanto, 2019; Maryanto \& Wulanata, 2018; Putra et al., 2014). Pembelajaran bahasa Indonesia diarahkan untuk meningkatkan kemampuan siswa dalam berkomunikasi menggunakan bahasa Indonesia secara baik dan benar yang meliputi empat aspek keterampilan, yaitu menyimak, berbicara, membaca, dan keterampilan menulis, sehingga pembelajaran Bahasa Indonesia di SD diharapkan agar dapat membantu siswa mengenal dirinya, budayanya dan budaya orang lain, mengemukakan gagasan dan perasaan, berpartisipasi dalam masyarakat dan menemukan serta menggunakan kemampuan imajinatif yang ada dalam dirinya (Astuti, 2016; Septiani \& Hasanah, 2019; Suria et al., 2019). Salah satu materi yang didapatkan pada pembelajaran Bahasa Indonesia di kelas IV SD yaitu gagasan pokok dan gagasan pendukung.

Gagasan pokok merupakan inti dari sebuah bacaan, letak dari gagasan pokok biasanya terdapat pada awal kalimat, akhir kalimat, atau awal dan akhir kalimat dalam paragraf teks bacaan, sedangkan gagasan pendukung merupakan kalimat penjelas dari ide pokok, gagasan pendukung diartikan sebagai gagasan yang fungsinya menjelaskan gagasan utama (Awatik, 2019; Santika et al., 2019; Semitayani \& Rasmini, 2020). Gagasan penjelas umumnya dinyatakan oleh lebih dari satu kalimat, kalimat yang mengandung gagasan penjelas disebut kalimat penjelas. Perbedaan gagasan pokok dan gagasan pendukung yaitu pada gagasan pokok kalimat-kalimat yang terdapat pada suatu paragraf hanya terfokus dengan isi dari topik paragraph sedangkan gagasan pendukung kalimatkalimat yang terdapat didalam suatu paragraf berisikan penjelasan dari topik utama yang dibahas di paragraf (Kurniasari, 2017; Mahardika, 2018; Putri et al., 2014). Sehingga untuk menentukan gagasan pokok dan gagasan pendukung dalam sebuah paragraf siswa harus memahami isi dari teks paragraf yang dibaca. Akan tetapi pada masa ini sangat sulit untuk mengajarkan pembiasaan membaca kepada siswa. Apalagi pada masa ini kegiatan pembelajaran dilakukan secara daring (pembelajaran jarak jauh) yang menyebabkan kesulitan bagi guru untuk mengontrol siwa dalam pelaksanaan pembelajaran khususnya dalam pembelajaran Bahasa Indonesia. Padahal pada dasarnya pembelajaran bahasa Indonesia itu bertujuan untuk dapat berkomunikasi dengan menggunakan Bahasa Indonesia dengan baik dan benar.

Berdasarkan hasil observasi dan wawancara yang telah dilakukan pada siswa kelas IV di SD Negeri 1 Suwat, diketahui bahwa kompetensi siswa dalam Bahasa Indonesia khususnya literasi masih berada pada kategori yang cukup rendah sehingga sulit untuk menemukan dan memahami bagaimana cara siswa menemukan gagasan pokok dan gagasan pendukung pada suatu teks atau paragraf. Masih banyak siswa yang bingung akan menentukan gagasan pokok dan gagasan pendukung dari sebuah paragraf atau bacaan dalam mata pelajaran Bahasa Indonesia. Selain itu penggunaan metode yang 
digunakan guru masih menggunakan metode konvensional atapun penggunaan media yang monoton, sehingga menyebabkan rendahnya hasil belajar siswa pada mata pelajaran Bahasa Indonesia. Jika hal ini terus dibiarkan maka akan berdampak pada perkembangan Bahasa dan hasil belar siswa. Maka dari itu, diperluka adanya suatu inovasi dalam pelaksanaan pembelajaran agar siswa dapat tertarik dalam mengikuti proses pembelajaran yaitu dengan cara melakukan pengembangan media pembelajaran sesuai dengan kebutuhan siswa. Salah satu media pembelajaran yang dapat dikembangkan yaitu media pembelajaran komik khususnya pada materi gagasan pokok dan gagasan pendukung.

Media komik merupakan sajian alur cerita yang berisi pesan atau informasi yang disajikan secara visual dalam bentuk gabungan gambar-gambar dan teks yang berurutan sebagai ekspresi dari pemerannya sehingga pembaca tertarik dan terhibur membaca komik (Budiarti \& Haryanto, 2016; Rakasiwi, 2019; Sukmanasa et al., 2017). Peranan komik sebagai media pembelajaran yaitu dipandang sangat efektif sebagai salah satu media untuk membelajarkan dan mengembangkan kreativitas siswa, sehingga media komik sangat cocok digunakan sebagai media pembelajaran salah satunya untuk mengajarkan siswa tentang cara menentukan gagasan utama dan gagasan pendukung dalam sebuah paragraf.

Media pembelajaran komik virtual dapat digunakan dalam pelaksanaan pembelajaran, karena media ini memiliki beberapa kelebihan yaitu (1) media pembelajaran komik digital dapat menarik perhatian siswa sehingga dapat meningkatkan minat dan antusias siswa dalam pembelajaran, (2) media komik yang dikemas secara virtual dapat diakses dengan mudah, dimana biasanya komik hanya bisa dijumpai dalam bentuk cetak/buku, (3) ilustrasi materi yang diberikan pada media komik digital dapat diberikan dalam bentuk atau contoh kongkrit mengenai maksud dari suatu materi sehingga siswa lebih mudah memahaminya, (4) media komik virtual ini juga dapat mengembangkan imajinasi yang dimiliki siswa. (Fadillah, 2018; Karmiani, 2018; Utariyanti et al., 2015).

Kata virtual dapat diartikan sebagai aktivitas yang dilakukan mirip dengan versi aslinya yang dalam prakteknya biasanya dibantu dengan sebuah teknologi seperti internet dan komputer sehingga dapat dengan mudah diakses baik oleh guru ataupun siswa (Dewi, 2020; Fitriyani et al., 2020; Salsabila et al., 2020). Apalagi media yang dapat dengan mudah diakses sangat diperlukan dalam pelaksanaan pembelajaran daring pada masa ini. Penggunaan komik virtual ini memungkinkan untuk menunjang pembelajaran yang bebas dikakses oleh siswa baik digunakan di sekolah maupun di rumah guna membantu dalam proses pembelajaran.

Beberapa penelitian yang terkait dalam pengembangan media komik ini yaitu: (1) penelitian yang dilakukan oleh (Budiarti \& Haryanto, 2016), yang memperoleh hasil penelitian bahwa Media Komik dihasilkan dinyatakan dapat meningkatkan motivasi belajar dan keterampilan membaca pemahaman siswa; (2) penelitian yang dilakukan oleh (Karmiani, 2018), yang memperoleh hasil penelitian bahwa Media Komik Berbahasa Inggris dinyatakan dapat meningkatkan kemampuan membaca pemahaman Bahasa Inggris pada siswa; (3) penelitian yang dilakukan oleh (Rakasiwi, 2019), yang memperoleh hasil penelitian bahwa media komik dengan metode picture and picture dinyatakan meningkatkan keterampilan literasi matematika pada siswa.

Tujuan dilaksanakan penelitian ini adalah untuk menganalisis pengembangan media pembelajaran daring Komik Virtual dalam muatan materi gagasan pokok dan gagasan pendukung Bahasa Indonesia pada siswa kelas IV di SD Negeri 1 Suwat.

\section{Metode}

Penelitian ini merupakan jenis penelitian pengembangan (Research and Development). Pelaksanaan penelitian ini mengacu kepada model penelitian pengembangan ADDIE (Analyze, Design, Development, Implementation, Evaluation). Model ADDIE merupakan model penelitian pengembangan yang berlandaskan pada pendekatan yang efektif dan efisien. Prosedur/tahapan penelitian yang dilakukan pada penelitian ini yaitu terdiri dari 5 tahapan yaitu: (1) Tahap Analisis; (2) Tahap perancangan; (3) Tahap Pengembangan; (4) Tahap Implementasi; (5) Tahap Evaluasi. Namun pelaksanaan penelitian ini hanya bisa dilakukan pada tahap Uji coba produk karena terkendala oleh situasi di lapangan yang masih dalam keadaan pandemi Covid-19 sehingga tidak memungkinkan untuk mengadakan uji coba produk dalam kegiatan pembelajaran di kelas.

Subjek penelitian ini adalah validitas media pembelajaran daring Komik Virtual dalam muatan materi gagasan pokok dan gagasan pendukung Bahasa Indonesia. Penelitian ini dilaksanakan untuk 
menganalisis pengembangan media pembelajaran daring Komik Virtual dalam muatan materi gagasan pokok dan gagasan pendukung Bahasa Indonesia pada siswa kelas IV di SD Negeri 1 Suwat.

Metode pengumpulan data yang digunakan dalam penelitian menggunakan metode non tes dengan penyebaran angket/kuisioner. Data yang dikumpulkan dalam penelitian ini yaitu data kuantitatif berupa skor/nilai yang didapatkan melalui penyebaran kuisoner/angket dan data kualitatif berupa komentar, saran, dan tanggapan yang diperoleh dari subjek uji coba terhadap media yang dikembangkan. Instrumen yang digunakan dalam penelitian ini berupa kuisioner/angket. Instrumen ini digunakan untuk mengumpulkan data hasi review dari ahli media, ahli desain pembelajaran, dan ahli materi, serta respon siswa pada saat uji coba perorangan. Adapun kisi-kisi dari kusioner/angket disajikan pada Tabel 1, Tabel 2, Tabel 3, dan Tabel 4.

Tabel 1. Kisi-kisi Instrumen Ahli Materi Pembelajaran

\begin{tabular}{ll}
\hline Aspek & \multicolumn{1}{c}{ Indikator } \\
\hline Kurikulum & Kesesuaian materi dengan KD. \\
& Keseimbangan materi dengan indikator. \\
& Kesesuaian materi dengan tujuan. \\
Isi/Materi & Kebenaran materi. \\
& Ketepatan materi. \\
& Pentingnya materi. \\
& Kedalaman materi. \\
& Kemenarikan materi. \\
& Kesesuaian materi dengan karakteristik siswa. \\
& Materi mudah untuk dipahami. \\
& Materi mempresentasikan kehidupan nyata. \\
& Konsep materi dapat dilogika dengan jelas. \\
& Menggunaan Bahasa yang tepat dan konsisten. \\
& Bahasa yang digunakan sesuai dengan karakteristik siwa. \\
& Kesesuaian intonasi kata/kalimat dengan karakteristik siswa. \\
\hline
\end{tabular}

Tabel 2. Kisi-kisi Instrumen Ahli Desain Pembelajaran

\begin{tabular}{ll}
\hline Aspek & \multicolumn{1}{c}{ Indikator } \\
\hline Tujuan & Kejelasan tujuan pembelajaran. \\
& Konsistensi tujuan, materi, dengan evaluasi. \\
& Penyampaian materi memberikan langkah-langkah yang logis dan \\
& alur navigasi yang bebas. \\
& Kegiatan pembelajaran dapat memotivasi siswa. \\
& Memberikan contoh-contoh dalam penyajiannya \\
& Penjelasan materi menarik dan sesuai dengan karakteristik siswa. \\
& Memberikan umpan balik hasil evaluasi. \\
& Soal yang disajikan sesuai dengan indikator dan tujuan \\
& pembelajaran atau materi. \\
& Kejelasan petunjuk pengerjaan soal. \\
&
\end{tabular}

Tabel 3. Kisi-kisi Instrumen Ahli Media Pembelajaran

\begin{tabular}{cl}
\hline Aspek & \multicolumn{1}{c}{ Indikator } \\
\hline Kelayakan & Media sesuai KD. \\
& Media sesuai indicator. \\
& Media sesuai dengan tujuan pembelajaran. \\
Ketepatan, Terkini, Kejelasan & Materi dalam media akurat. \\
& Materi dalam media terkini. \\
& Materi jelas dalam menjelaskan konsep. \\
& Materi tidak bias.
\end{tabular}




\begin{tabular}{cl}
\hline Aspek & \\
\hline Tampilan & Teks. \\
& Gambar. \\
& Warna. \\
& Animasi. \\
& Suara. \\
& Video. \\
\hline
\end{tabular}

Tabel 4. Kisi-kisi Instrumen Uji Coba Siswa

\begin{tabular}{cl}
\hline Aspek & \multicolumn{1}{c}{ Indikator } \\
\hline Media & Kemenarikan pembelajaran menggunakan komik virtual. \\
& Kemudahan penggunaan. \\
& Kemenarikan tampilan komik virtual. \\
& Keefektifan komik virtual. \\
& Kejelasan petunjuk penggunaan komik virtual. \\
& Kemudahan materi dipelajari. \\
& Kebermanfaatan materi. \\
& Kejelasan soal evaluasi. \\
& Kejelasan umpan balik. \\
& Interaktifitas media. \\
& Meningkatkan minat belajar. \\
& Pemberian contoh. \\
\hline
\end{tabular}

Teknik analisis data yang digunakan dalam penelitian ini adalah teknik analisis statistik deskriptif kuantitatif. Teknik ini digunakan untuk mengolah hasil angket/kuisioner dari para ahli dan uji coba perorangan berupa skor dengan menggunakan skala likert yang dimodifikasi. Kemudian hasil perhitungan skor-skor yang diperoleh melalui angket diubah dalam bentuk persentase respon dari masing-masing subjek dengan kriteria yang ditetapkan untuk memberikan makna dan pengambilan keputusan yaitu menggunakan Konversi Tingkat Pencapaian dengan Skala 5.

\section{Hasil dan Pembahasan}

Hasil penelitian pengembangan ini adalah media pembelajaran komik virtual dalam muatan materi gagasan pokok dan gagasan pendukung Bahasa Indonesia untuk siswa kelas IV SD. Penelitian ini dilaksanakan di Sekolah Dasar Negeri 1 Suwat. Rancangan pengembangan media pembelajaran komik virtual dalam muatan materi gagasan pokok dan gagasan pendukung Bahasa Indonesia ini mengacu kepada tahap-tahap model ADDIE yang terdiri dari lima tahap yaitu analisis, desain, pengembangan, implementasi, dan evaluasi.

Tahap pertama, yaitu tahap analisis. Pada tahap ini kegiatan yang dilakukan yaitu mengadakan observasi dan wawancara di SD N 1 Suwat terkait dengan analisis kebutuhan guru dan siswa dalam pembelajaran, analisis fasilitas sekolah dan analisis terhadap materi yang sesuai dengan pengembangan media yang dilakukan. Berdasarkan hasil wawancara yang telah dilakukan dengan guru kelas IV didapatkan hasil bahwa dalam pelaksanaan pembelajaran guru masih menggunakan buku tematik sebagai sumber belajar utama bagi siswa dan terkadang menggunakan media lain seperti gambar-gambar yang ada di buku siswa ataupun video yang didapatkan dari youtube, dari segi pembelajaran siswa mengalami kesulitan dalam memahami pengertian dari gagasan pokok dan gagasan penjelas/pendukung, kurangnya kosakata yang dimiliki, kesulitan jika menemukan kalimat yang panjang, dan teknik-teknik dalam menemukan ide pokok teks bacaan pada paragraf teks bacaan. Berdasarkan hasil observasi yang telah dilakukan dilihat dari segi kelengkapan fasilitas sekolah di SDN 1 Suwat sudah terdapat LCD Proyektor, Speaker, computer yang masih berfungsi dengan baik.

Tahap kedua, yaitu desain, pada tahap ini kegiatan yang dilakukan meliputi perancangan story board Komik Virtual, perancangan tampilan, dan pemilihan karakter yang akan digunakan dalam pengembangan media Komik Virtual. Tahap ketiga, yaitu pengembangan. Pada tahap ini kegiatan yang dilakukan meliputi (1) recreating comic yaitu perealisasian dari story board yang telah dibuat dimana dalam pembuatannya dibantu dengan menggunakan aplikasi Microsoft Office Power Point. (2) 
virtualisasi yaitu tahap pengubahan komik dari bentuk powerpoint dirubah atau di convert dalam bentuk video. (3) uji kelayakan produk. Tahap keempat, yaitu implementasi. Pada tahap ini kegiatan yang dilakukan yakni penerapan media yang dikembangkan dalam pelaksanaan pembelajaran di kelas, namun karena pada masa penelitian masih pada masa pandemi sehingga tidak memungkinkan untuk melaksanakan pembelajaran secara langsung di kelas. Maka dari itu pada tahap implementasi ini tidak bisa dilaksanakan pada penelitian. Tahap kelima, yaitu evaluasi. Pada tahap ini evaluasi yang dilakukan berupa evaluasi secara formatif, kegiatan evaluasi dilakukan selama proses pengembangan produk media pembelajaran tujuannya untuk menghindari terjadinya kesalahan pada hasil akhir produk. Evaluasi dilakukan pada proses tahap pengembangan yaitu pada tahap analisis, tahap desain, dan tahap pengembangan.

Uji validitas produk dilaksanakan guna untuk menguji tingkat kelayakan produk yang telah dikembangkan. Pengujian validitas produk yang dikembangkan dilakukan dengan pemberian kusioner kepada para ahli uji validitas yang terdiri dari ahli isi mata pelajaran, ahli desain pembelajaran, ahli media pembelajaran, dan uji coba perorangan terkait dengan produk yang dikembangkan. Hasil uji validitas pengembangan media komik virtual dari ahli isi mata pelajaran, ahli desain pembelajaran, ahli media pembelajaran, dan uji coba perorangan disajikan pada Tabel 5.

Tabel 5. Persentase Hasil Validitas Pengembangan Media Pembelajaran Komik Virtual

\begin{tabular}{lcc}
\hline Subjek Uji Coba & Hasil Validitas & Keterangan \\
\hline Uji Isi Mata Pelajaran & $90,00 \%$ & Sangat Baik \\
Uji Desain Pembelajaran & $92,00 \%$ & Sangat Baik \\
Uji Media Pembelajaran & $95,00 \%$ & Sangat Baik \\
Uji Perorangan & $92,35 \%$ & Sangat Baik \\
\hline
\end{tabular}

Berdasarkan Tabel 5, diketahui bahwa hasil uji valditas pengembangan media pembelajaran komik virtual secara keseluruhan memiliki persentase yang sangat baik. Hal ini terlihat dari hasil uji coba oleh ahli isi mata pelajaran diperoleh persentase sebesar 90,00\%, ahli desain pembelajaran diperoleh persentase sebesar 92,00\%, ahli media pembelajaran diperoleh persentase sebesar 95,00\%, dan hasil uji coba perorangan diperoleh persentase sebesar 92,00\%. Sehingga, berdasarkan hasil uji validitas tersebut menyatakan bahwa media pembelajaran komik virtual yang dikembangkan layak untuk digunakan walau terdapat sedikit masukan guna penyempurnaan produk. Adapun hasil pengembangan media pembelajaran komik virtual disajikan pada Gambar 1 dan Gambar 2.

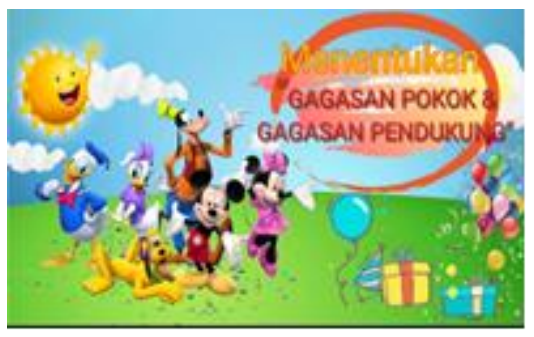

Gambar 1. Media Pembelajaran Komik Virtual

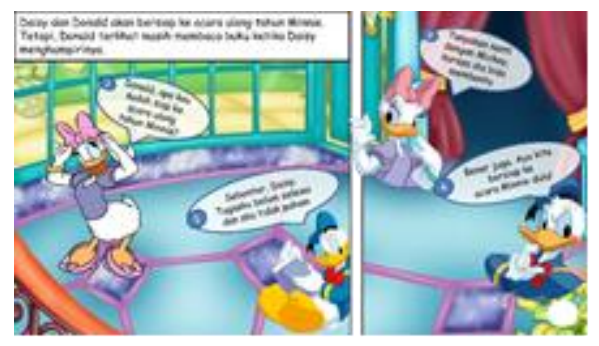

Gambar 2. Isi Media Pembelajaran Komik Virtual

Berdasarkan hasil uji validitas oleh tim ahli dan hasil uji coba perorangan media pembelajaran komik virtual yang dikembangkan telah memenuhi kriteria kelayakan baik dari segi isi mata pelajaran, desain pembelajaran, dan media pembelajaran, sehingga dapat digunakan dalam pembelajaran khususnya pada muatan materi gagasan pokok dan gagasan pendukung Bahasa Indonesia siswa kelas IV SD. Kelayakan yang diperoleh dari pengembangan media pembelajaran komik virtual ini tentunya tidak terlepas dari pemilihan model yang tepat yang digunakan dalam penelitian ini yaitu mengacu pada model ADDIE. Model ADDIE merupakan salah satu model pengembangan yang memiliki langkahlangkah sistemastis dalam upaya pemecahan masalah belajar yang berkaitan dengan sumber belajar yang sesuai dengan kebutuhan dan karakteristik siswa, dimana model ini terdiri dari lima tahapan yaitu: (1) Tahap analisis (Analyze); (2) Tahap merancang (Design); (3) Tahap mengembangkan (Development); (4) Tahap mengiplementasikan (Implementation); (5) Tahap mengevaluasi (Evaluation). Selain itu, kelayakan media pembelajaran komik virtual ini juga dipengaruhi oleh 
kevalidan produk yang dikembangkan yang terdiri dari aspek isi mata pelajaran, aspek desain pembelajaran, aspek media pembelajaran, dan hasil uji coba perorangan.

Berdasarkan hasil review oleh ahli isi mata pelajaran media pembelajaran komik virtual ini memperoleh presentase sebesar 90,00\% yang berada pada kualifikasi sangat baik. Hal tersebut diperoleh dari beberapa hal yaitu dalam aspek kurikulum media yang disajikan sudah memperhatikan kesesuaian materi dengan kompetensi dasar, indikator, dan tujuan pembelajaran yang disajikan dalam komik virtual dan dalam aspek isi/materi media sudah disajikan dengan menarik, memperhatiakan kesesuaian materi dengan karakteristik siswa dan materi mudah dipahami dalam media komik virtual. Untuk menganalisis validasi media pembelajaran ada beberapa indikator yang harus terpenuhi diantaranya kesesuaian materi media dengan materi pembelajaran, kompetensi dasar, indikator dan tujuan pembelajaran, keseimbangan antara penyajian isi materi dengan tujuan pembelajaran, dan pemilihan Bahasa yang disesuaikan dengan karakteristik siswa (Dewi, 2020; Fitriyani et al., 2020; Salsabila et al., 2020).

Berdasarkan hasil review ahli desain pembelajaran media pembelajaran komik virtual ini memperoleh presentase sebesar $92,00 \%$ yang berada pada kualifikasi sangat baik. Untuk tercapai hal tersebut dikarenakan media yang dikembangkan sudah memperhatikan penggunaan gambar, simbol, warna dan bahasa yang digunakan dalam penyampaian materi. Faktor yang dapat membuat media komik menarik yakni materi dilengkapi dengan gambar-gambar kemudian dikemas secara menarik, pemilihan dan pembuatan gambar-gambar harus terlihat jelas, kesesuaian warna yang digunakan, dan pemilihan jenis huruf, serta desain tampilan komik dibuat agar dapat menarik perhatian (Fadillah, 2018; Karmiani, 2018; Utariyanti et al., 2015).

Berdasarkan hasil review ahli media pembelajaran media pembelajaran komik virtual ini memperoleh presentase sebesar 95,00\% yang berada pada kualifikasi sangat baik. Perolehan ini dikarenakan media yang dikembangakan sudah sesuai dengan kriteria-kriteria pemilihan media pembelajaran baik dari segi isi, tampilan, dan kelayakan. Pemilihan media ada beberapa kriteria yang harus diperhatikan yaitu kesesuaian dengan tujuan (instructional goals), kesesuaian dengan materi pembelajaran (instructional content), kesesuaian dengan karakteristik pembelajar atau siswa, kesesuaian dengan teori, kesesuain dengan gaya belajar siswa, dan kesesuaian dengan kondisi lingkungan, fasilitas, pendukung, dan waktu yang tersedia (Budiarti \& Haryanto, 2016; Rakasiwi, 2019; Sukmanasa et al., 2017). Selain itu, pengembangan media yang dilakukan dari segi tampilan dan suara narator memiliki suara yang ekspresif dan terdengar dengan jelas sehingga dapat memotivasi siswa dalam pembelajaran.

Setelah dilakukan penilaian oleh para ahli dan media yang dikembangkan dinyatakan layak untk digunakan kemudian produk dapat di uji cobakan kepada siswa. Tahap uji coba ini terdiri dari satu tahap yaitu uji coba perorangan. Berdasarkan hasil uji coba perorangan yang melibatkan 3 responden diperoleh persentase sebesar 92,35\% dengan kualifikasi sangat baik. Perolehan kualifikasi sangat baik ini dikarenakan media pembelajaran komik virtual ini membuat siswa merasa senang dan termotivasi dalam menyimak pembelajaran yang diberikan. Dengan adanya media pembelajaran komik siswa dapat dengan mudah menggambarkan keadaan terkait dengan materi yang diberikan dalam kehidupan sehari-hari sehingga pembelajaran menjadi lebih menarik dan mudah untuk dimengerti oleh siswa (Rakasiwi, 2019; Rohati et al., 2018; Wicaksono et al., 2020).

Media komik merupakan sajian alur cerita yang berisi pesan atau informasi yang disajikan secara visual dalam bentuk gabungan gambar-gambar dan teks yang berurutan sebagai ekspresi dari pemerannya sehingga pembaca tertarik dan terhibur membaca komik (Budiarti \& Haryanto, 2016; Rakasiwi, 2019; Sukmanasa et al., 2017). Peranan komik sebagai media pembelajaran yaitu dipandang sangat efektif sebagai salah satu media untuk membelajarkan dan mengembangkan kreativitas siswa, sehingga media komik sangat cocok digunakan sebagai media pembelajaran salah satunya untuk mengajarkan siswa tentang cara menentukan gagasan utama dan gagasan pendukung dalam sebuah paragraf.

Media pembelajaran komik virtual dapat digunakan dalam pelaksanaan pembelajaran, karena media ini memiliki beberapa kelebihan yaitu (1) media pembelajaran komik digital dapat menarik perhatian siswa sehingga dapat meningkatkan minat dan antusias siswa dalam pembelajaran, (2) media komik yang dikemas secara virtual dapat diakses dengan mudah, dimana biasanya komik hanya bisa dijumpai dalam bentuk cetak/buku, (3) ilustrasi materi yang diberikan pada media komik digital dapat diberikan dalam bentuk atau contoh kongkrit mengenai maksud dari suatu materi sehingga 
siswa lebih mudah memahaminya, (4) media komik virtual ini juga dapat mengembangkan imajinasi yang dimiliki siswa. (Fadillah, 2018; Karmiani, 2018; Utariyanti et al., 2015).

Kata virtual dapat diartikan sebagai aktivitas yang dilakukan mirip dengan versi aslinya yang dalam prakteknya biasanya dibantu dengan sebuah teknologi seperti internet dan komputer sehingga dapat dengan mudah diakses baik oleh guru ataupun siswa (Dewi, 2020; Fitriyani et al., 2020; Salsabila et al., 2020). Apalagi media yang dapat dengan mudah diakses sangat diperlukan dalam pelaksanaan pembelajaran daring pada masa ini. Penggunaan komik virtual ini memungkinkan untuk menunjang pembelajaran yang bebas dikakses oleh siswa baik digunakan di sekolah maupun di rumah guna membantu dalam proses pembelajaran.

Beberapa penelitian yang terkait dalam pengembangan media komik ini yaitu: (1) penelitian yang dilakukan oleh (Budiarti \& Haryanto, 2016), yang memperoleh hasil penelitian bahwa Media Komik dihasilkan dinyatakan dapat meningkatkan motivasi belajar dan keterampilan membaca pemahaman siswa; (2) penelitian yang dilakukan oleh (Karmiani, 2018), yang memperoleh hasil penelitian bahwa Media Komik Berbahasa Inggris dinyatakan dapat meningkatkan kemampuan membaca pemahaman Bahasa Inggris pada siswa; (3) penelitian yang dilakukan oleh (Rakasiwi, 2019), yang memperoleh hasil penelitian bahwa media komik dengan metode picture and picture dinyatakan meningkatkan keterampilan literasi matematika pada siswa.

Temuan-temuan yang didapat dari pelaksanaan penelitian ini memberikan implikasi yaitu media pembelajaran komik virtual dalam muatan materi gagasan pokok dan gagasan pendukung Bahasa Indonesia dapat digunakan guru sebagai salah satu sumber belajar sehingga dapat meningkatkan minat siswa dalam pembelajaran di kelas. Selain itu, pengembangan media ini juga dapat memotivasi atau mendorong guru untuk memanfaatkan sarana dan prasarana di sekolah yang selama ini jarang dimanfaatkan, serta dapat mengasah kemampuan guru dalam memanfaatkan kemajuan teknologi untuk memajukan pendidikan dan secara tidak langsung hal ini berdampak juga pada kemampuan guru dalam mengoperasikan media pendukung yakni laptop dan LCD projector dan paket internet.

\section{Simpulan}

Simpulan penelitian ini adalah media pembelajaran daring Komik Virtual secara keseluruhan termasuk kedalam kategori sangat baik dan layak untuk digunakan dalam pembelajaran muatan Bahasa Indonesia materi gagasan pokok dan gagasan pendukung pada siswa kelas IV di SD Negeri 1 Suwat. Implikasi dari pelaksanaan penelitian ini adalah dapat digunakan oleh guru sebagai sumber belajar sehingga dapat meningkatkan minat siswa untuk belajar.

\section{Daftar Pustaka}

Anugrahana, A. (2020). Hambatan, Solusi dan Harapan: Pembelajaran Daring Selama Masa Pandemi Covid-19 Oleh Guru Sekolah Dasar. Jurnal Scholaria, 10(3), 282-289. https://doi.org/10.24246/j.js.2020.v10.i3.p282-289.

Astuti, A. P. (2016). Pengembangan Instrumen Penilaian Kompetensi Membaca Pada Mata Pelajaran Bahasa Indonesia Kelas VII Berbasis Quipper School. JINoP (Jurnal Inovasi Pembelajaran), 2(2), 334-350. https://doi.org/10.22219/jinop.v2i2.3635.

Awatik, A. (2019). Pembelajaran Dengan Cooperative Integrated Reading And Composition (CIRC) Dalam Meningkatkan Kemampuan Menemukan Pokok Pikiran. Trapsila: Jurnal Pendidikan Dasar, 2(1). https://doi.org/10.30742/tpd.v1i02.813.

Budi Febriyanto. (2019). Metode Cerita Berantai Untuk Meningkatkan Keterampilan Berbicara Siswa Pada Pembelajaran Bahasa Indonesia. Jurnal Cakrawala Pendas, 5(2), 40-44. https://doi.org/10.31949/jcp.v5i2.1388.

Budiarti, W. N., \& Haryanto, H. (2016). Pengembangan Media Komik Untuk Meningkatkan Motivasi Belajar Dan Keterampilan Membaca Pemahaman Siswa Kelas IV. Jurnal Prima Edukasia, 4(2), 233. https://doi.org/10.21831/jpe.v4i2.6295.

Dewi, E. U. (2020). Pengaruh Kecemasan Saat Pembelajaran Daring Masa Pandemi Covid-19 Terhadap Prestasi Belajar Mahasiswa Stikes William Surabaya. Jurnal Keperawatan, 9(1). https://doi.org/10.47560/kep.v9i1.210.

Fadillah, A. (2018). Pengembangan Media Belajar Komik Terhadap Motivasi Belajar Siswa. JTAM / 
Jurnal Teori Dan Aplikasi Matematika, 2(1), 36. https://doi.org/10.31764/jtam.v2i1.259.

Fitriyani, Y., Fauzi, I., \& Sari, M. Z. (2020). Motivasi Belajar Mahasiswa Pada Pembelajaran Daring Selama Pandemik Covid-19. Jurnal Kependidikan: Jurnal Hasil Penelitian Dan Kajian Kepustakaan Di Bidang Pendidikan, Pengajaran Dan Pembelajaran, 6(2), 165-175. https://doi.org/10.23917/ppd.v7i1.10973.

Karmiani, S. (2018). Penggunaan Media Komik Berbahasa Inggris Sebagai Upaya Meningkatkan Kemampuan Membaca Pemahaman Bahasa Inggris Pada Siswa Kelas Viii Smpn 3 Teluk

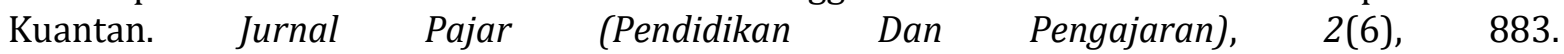
https://doi.org/10.33578/pjr.v2i6.6514.

Kurniasari, F. (2017). Implementasi Pendekatan Saintifik Pada Penugasan Aktivitas Di Buku Teks Bahasa Indonesia Kelas VII SMP Berdasarkan Kurikulum 2013. Jurnal Pendidikan Edutama, 4(1), 9-26. https://doi.org/10.30734/jpe.v4i1.44.

Mahardika, B. (2018). Penerapan Metode Penilaian Berbasis Portofolio Dalam Meningkatkan Pembelajaran Bahasa Indonesia. Elementary: Jurnal Ilmiah Pendidikan Dasar, 4(1), 33-46. https://doi.org/10.32332/elementary.v4i1.1030.

Maharwati, N. K. (2019). Upaya Meningkatkan Kemampuan Berbahasa Lisan Anak Paud Berbantuan Media Gambar Melalui Metode Bercerita. Journal of Education Technology, 2(1), 6. https://doi.org/10.23887/jet.v2i1.13800.

Maryanto, R. I. P., \& Wulanata, I. A. (2018). Penggunaan Media Flashcard Untuk Meningkatkan Pengenalan Bentuk Huruf Siswa Kelas I Pada Mata Pelajaran Bahasa Indonesia Di Sekolah ABC Manado. Pedagogia: Jurnal Ilmu Pendidikan, 16(3). https://doi.org/10.17509/pdgia.v16i3.12073.

Maufur, S., \& Lisnawati, S. (2017). Pengaruh Penggunaan Media Gambar Berseri Terhadap Keterampilan Berbicara Bahasa Indonesia Siswa Kelas III MI Al-Washliyah Perbutulan Kabupaten Cirebon. Al Ibtida: Jurnal Pendidikan Guru MI, 4(2), 189. https://doi.org/10.24235/al.ibtida.snj.v4i2.1888.

Putra, P. A., Agung, A. A. G., \& Sulastri, N. M. (2014). Pengaruh Model Pembelajaran Scramble Berbantuan Media Permainan Teka-teki Silang Terhadap Hasil Belajar Bahasa Indonesia Siswa Kelas V Semester Ganjil Tahun Pelajaran 2013/2014 di SD Negeri 1 Sangsit Kecamatan Sawan Kabupaten Buleleng. Jurnal Mimbar PGSD Universitas Pendidikan Ganesha, 2(1), 1-12. https://doi.org/10.23887/jjpgsd.v2i1.2929.

Putri, I. G. A. C. A., Putra, D. K. N. S., \& Zulaikha, S. (2014). Pengaruh Metode Pembelajaran SQ3R Terhadap Hasil Belajar Bahasa Indonesia Kelas V SD. Mimbar PGSD Undiksha, 2(1). https://doi.org/10.23887/jjpgsd.v2i1.2471.

Putria, H., Maula, L. H., \& Uswatun, D. A. (2020). Analisis Proses pembelajaran Dalam Jaringan (DARING) Masa Pandemi Covid-19 pada Guru Sekolah Dasar. Jurnal Basicedu, 4(4), 861-872. https://doi.org/10.31004/basicedu.v4i4.460.

Rakasiwi, N. (2019). Pengembangan media komik dengan metode picture and picture untuk meningkatkan keterampilan literasi matematika kelas IV. Aksioma: Jurnal Matematika Dan Pendidikan Matematika, 10(1), 60-70. https://doi.org/10.26877/aks.v10i1.3741.

Rohati, Winarni, S., \& Hidayat, R. (2018). Pengembangan Media Pembelajaran Komik Matematika Berbasis Problem Based Learning dengan Manga Studio V05 dan Geogebra. Edumatica, 08(02), 81-91. https://doi.org/10.22437/edumatica.v8i2.5486.

Salsabila, U. H., Seviarica, H. P., \& Hikmah, M. N. (2020). Urgensi Penggunaan Media Audiovisual dalam Meningkatkan Motivasi Pembelajaran Daring di Sekolah Dasar. Insania: Jurnal Pemikiran Alternatif Kependidikan, 25(2), 284-304. https://doi.org/10.24090/insania.v25i2.4221.

Santika, Y. M., Kurniaman, O., \& Antosa, Z. (2019). Pengaruh Model Pembelajaran Cooperative Integrated Reading And Composition (CIRC) Terhadap Kemampuan Menentukan Ide Pokok Paragraf Siswa Kelas V SD Negeri 003 Pulau Kopung Kecamatan Sentajo Raya Kabupaten Kuantan Singingi. Jurnal Pajar (Pendidikan Dan Pengajaran), 3(2), 306-312. https://doi.org/10.33578/pjr.v3i2.6355.

Semitayani, N. K. A., \& Rasmini, N. K. (2020). Reaksi Pasar terhadap Publikasi Opini Wajar Tanpa Pengecualian dengan Paragraf Penekanan Suatu Hal. E-Jurnal Akuntansi, 30(12), 3136-3149. https://doi.org/10.24843/EJA.2020.v30.i12.p11.

Septiani, M. T., \& Hasanah, M. (2019). Media Audio Visual untuk Pembelajaran Musikalisasi Puisi. 
BASINDO: Jurnal Kajian Bahasa, Sastra Indonesia, Dan Pembelajarannya, 3(1), 31-37. https://doi.org/10.17977/um007v3i12019p031.

Sukmanasa, E., Windiyani, T., \& Novita, L. (2017). Pengembangan Media Pembelajaran Komik Digital Pada Mata Pelajaran Ilmu Pengetahuan Sosial Bagi Siswa Kelas V Sekolah Dasar Di Kota Bogor. Jurnal Pendidikan Sekolah Dasar, 3(2), 171. https://doi.org/10.30870/jpsd.v3i2.2138.

Suria, M. D. O., Suwatra, I. W., \& Murda, N. (2019). Pengaruh Model Pembelajaran Snowball Throwing Berbantuan Media Audiovisual terhadap Hasil Belajar Bahasa Indonesia. Jurnal Ilmiah Sekolah Dasar, 3(1), 89. https://doi.org/10.23887/jisd.v3i1.17662.

Ulfah, D. M., \& Soenarto, S. (2017). Pengaruh penggunaan media video dan gambar terhadap keterampilan menulis kelas V. Jurnal Prima Edukasia, 5(1), 22-34. https://doi.org/10.21831/jpe.v5i1.7693.

Utariyanti, I. F. Z., Wahyuni, S., \& Zaenab, S. (2015). Pengembangan Media Pembelajaran Berbasis Komik Dalam Materi Sistem Pernapasan Pada Siswa Kelas VIII MTs Muhammadiyah 1 Malang. Jurnal Pendidikan Biologi Indonesia, 1(3), 343-355. https://doi.org/10.22219/jpbi.v1i3.2668.

Wicaksono, A. G., Jumanto, \& Oka, I. (2020). Pengembangan media komik komsa materi rangka pada pembelajaran IPA di sekolah dasar. Premiere Educandum: Jurnal Pendidikan Dasar Dan Pembelajaran, 10(2), 215-226. https://doi.org/10.25273/pe.v10i2.6384

Yunitasari, R., \& Hanifah, U. (2020). Pengaruh Pembelajaran Daring terhadap Minat Belajar Siswa pada Masa COVID 19. Edukatif: Jurnal Ilmu Pendidikan, 2(3), 236-240. https://doi.org/10.31004/edukatif.v2i3.142. 